\title{
DIVERSITY OF ICHTHYOFAUNA OF FENI AND MUHURI RIVERS, FENI, BANGLADESH
}

\author{
Sumana Yeasmin, Gulshan Ara Latifa and Gawsia Wahidunnessa Chowdhury* \\ Department of Zoology, University of Dhaka, Dhaka-1000, Bangladesh
}

\begin{abstract}
Diversity of ichthyofauna of Feni and Muhuri rivers was studied from April, 2015 to March 2016. The selected rivers were surveyed to cover the wet season (April 2015-September 2015) and the dry season (October 2015-March 2016). A total of 65 freshwater fish species belonging to 11 orders, 29 families were recorded from the two rivers. Of the 65 species, 12 species were threatened, and one species was identified as data deficient according to IUCN Bangladesh. Perciformes was recorded as most dominating order (19 species, among the 54 species recorded) in Feni river, whereas the Cypriniformes was recorded as the dominating order (17 species among the 42 species recorded from this river) in Muhuri river. Corica soborna was the most common species with the highest number of individuals in comparison to other fish species recorded from two rivers in both wet and dry seasons. Calculating the Shannon-Weiner and Simpson's indices of diversity and species evenness, highest number of species and individuals were found in the wet season while minimum in the dry season from both the rivers.
\end{abstract}

Key words: Ichthyofauna, Feni River, Muhuri River, status.

\section{INTRODUCTION}

Bangladesh (between $20^{\circ} 34^{\prime} \mathrm{N}$ and $26^{\circ} 38^{\prime} \mathrm{N}$ latitude and between $88^{\circ} 01^{\prime} \mathrm{E}$ and $92^{04} 1^{\prime} \mathrm{E}$ longitude in South Asia) is bordered by India to the north, east and west and Myanmar for a small portion in the south-east (Akonda 1989). The entire south of the country is occupied by the Bay of Bengal (Akonda 1989). The pride of Bangladesh is its rivers, with one of the largest networks in the world and a total of about 700 rivers, including the Ganges-Brahmaputra River Delta that acts as a drainage outlet for a vast river basin complex. This gives the country a reverent nature which is reflected in the lifestyle, custom, economy and history of the people of Bangladesh (Islam and Gnauck 2008). Due to its unique geophysical location; Bangladesh is exceptionally characterised by its rich biological diversity (Nishat et al. 2002). A total of about 253 freshwater fish species are recorded from Bangladesh (IUCN 2015).

Fisheries sector plays a very important role in the national economy of our country, about $60 \%$ of total animal protein comes from the fisheries sector (DOF 2013). Bangladesh has also been ranked as fourth in inland capture fisheries production, and fifth in the aquaculture production all over the world (FRSS

*Author of correspondence: <gawsia@gmail.com/gawsia@du.ac.bd>.

(C) 2017 Zoological Society of Bangladesh DOI: http://dx.doi.org/10.3329/bjz.v45i1.34194 
2015). During the last seven years, the aquaculture production became almost double which was 1.006 million MT in 2007-08 and 1.957 million MT in 201314 (FRSS 2015).

Ichthyofauna recorded from the freshwaters of Bangladesh is rich (Akonda 1989, DOF 2013, Siddique et al. 2007) but ichthyodiversity is facing different categories of threats. According to Allan and Flecker (1993), five foremost threats have been identified as: (1) lack of stock taking and introduction of non-native fish species, (2) river regulation and water diversion, (3) degradation of water quality (pollution and eutrophication), (4) habitat destruction and (5) overexploitation.

Globally, many freshwaters are considered to be ecologically degraded and biodiversity losses in freshwaters may be higher than those in the most affected terrestrial ecosystems (Dudgeon et al. 2006). The highest number of threatened freshwater fish is in south-east Asia (Baillie et al. 2010) and Bangladesh is not an exception.

The Feni and Muhuri Rivers are two of the major rivers of Bangladesh. The Bangladesh Water Development Board (BWDB) completed the construction of a cross-dam and regulator in the mouth of the Feni river in June, 1986 for flood control and irrigation in an area of about 694 sq. $\mathrm{km}^{2}$ in Feni, Chagalnaiya and Sonagazi Upazillas of Feni district created a shallow reservoir in the Feni river estuary, which would stabilize the water levels in three rivers of the area, the Feni and the Muhuri rivers are two of them in the area (Ameen 1987).

The objectives of the present study were to find out the diversity, seasonal abundance and conservation status of ichthyofauna of the two rivers. The findings of this study also intended to form a baseline for long term research and effective conservation management action plan for the threatened freshwater fish species.

\section{MATERIAL AND METHODS}

Study area: The study was conducted in the Feni river (upazila - Feni Sadar; village - Shibpur, Kalibari, Jelepara) and Muhuri River (upazila - Chhagalnaiya; village - Sonapur, Jelepara) of Feni district (Fig. 1). The Muhuri river is the upper tributary of the Feni, a major river in Bangladesh which meets the Sandweep channel at south-west region. From both rivers, three sites were selected for survey as per the discussion with the knowledgeable fishermen of the selected areas. The selected sites that lie in three different locations of Feni and Muhuri Rivers are: (1) Muhuri project of the Feni river in Sonapur village of Chhagalnaiya upazila which lies $22^{\circ} 50^{\prime} 08.9^{\prime \prime} \mathrm{N}$ to $91^{\circ} 27^{\prime} 17.8^{\prime \prime} \mathrm{E}$ latitude and longitude respectively; (2) Muhuri river where it meets with the Feni river in 
Alokdia of Feni Sadar upazilla which lies $22^{\circ} 54^{\prime} 42.4^{\prime \prime} \mathrm{N}$ to $91^{\circ} 30^{\prime} 09.9^{\prime \prime} \mathrm{E}$; and (3) Lemua bridge of Muhuri river which lies $22^{\circ} 55^{\prime} 03.6^{\prime \prime}$ to $91^{\circ} 28^{\prime} 34.0^{\prime \prime}$ latitude and longitude, respectively.

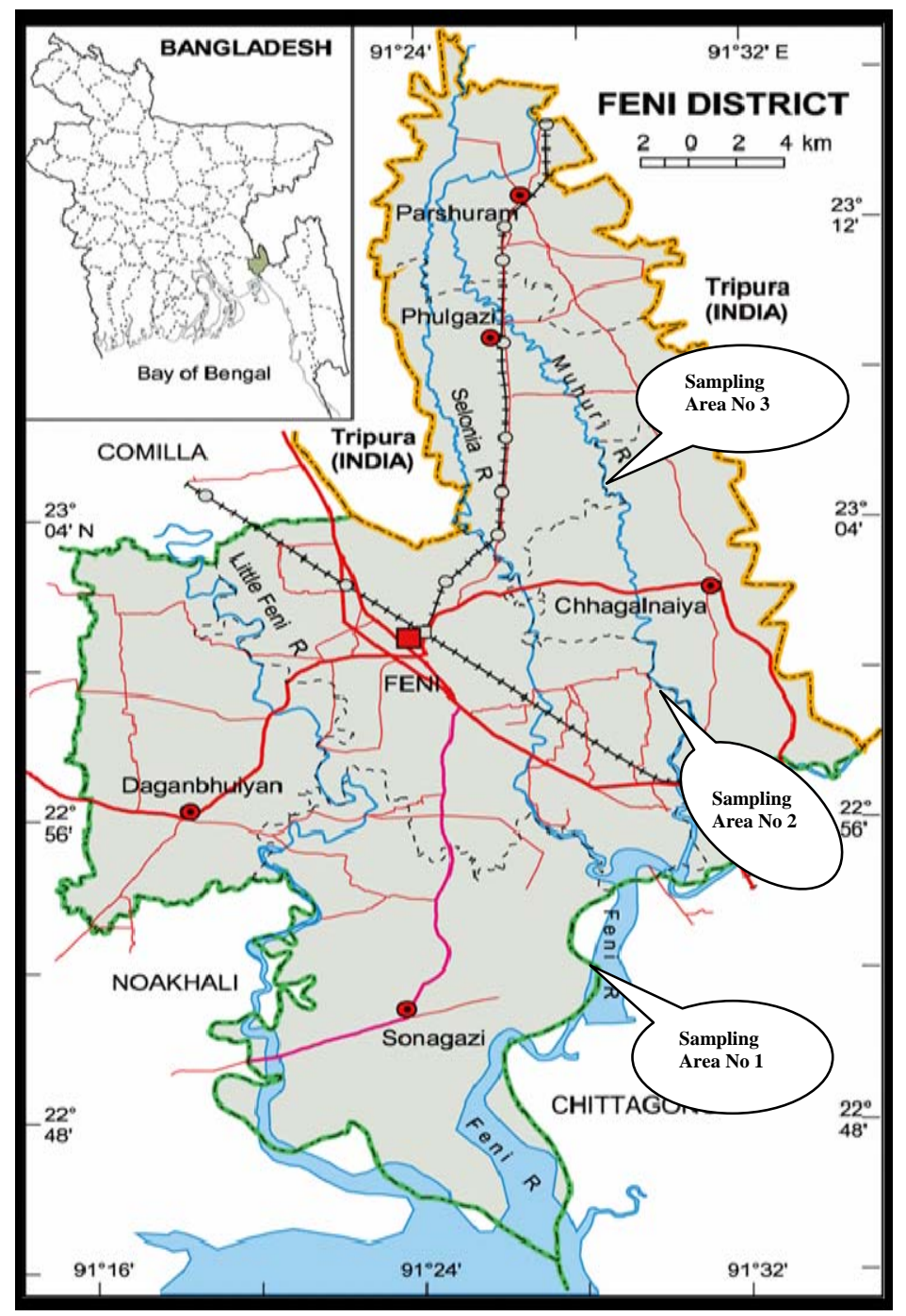

Fig. 1. The map showing sampling areas of Feni and Muhuri Rivers.

Data collection, taxonomic identification: Samples were collected through regular visits to fishing as well as landing centres and the fish markets adjacent to the selected areas. Primary data were collected by observing the fish catch of the fishermen, followed by the structured questionnaire interviews, focus group 
discussion (FGD) and cross-checked interviews. Some voucher specimens were collected for further clarification. Fishermen, fish traders and fish farmers were also consulted. Specimens were identified using the keys of Hamilton (1822), Siddique et al. (2007), Rahman et al. (2009), IUCN Red List (2015), etc.

Data analyses: There were several steps like data processing and tabulating of data, Statistical and mathematical analysis. The diversity indices were calculated (Allan and Flecker 1993) by using the following formulas:

Shannon-Weiner diversity index $H^{\prime}=\Sigma P i \times \log P i$

[where $P i=$ No. of individuals of species $\mathrm{i} /$ total no. of sample; $\mathrm{S}=$ No. of species richness; $H^{\prime}=$ maximum diversity possible]

Pielou's Evenness Index $\mathrm{J}^{\prime}=\mathrm{H}_{(\mathrm{S})} / \mathrm{H}_{(\max )}$ [where $\mathrm{H}_{(\mathrm{S})}=$ No. derived from Shannon-Weiner diversity index; $\mathrm{H}(\max )=$ Maximum possible value of $\mathrm{H} ; \mathrm{J}^{\prime}=$ Constrained between 0 and 1 ]

Simpson Dominance Index, D $=\sum_{i=1}^{z}\left(\frac{n i}{N}\right)^{2}$ and Simpson Index $=1-\mathrm{D}$

[D measures probability that two individuals randomly selected from a sample of same species; $\mathrm{n}=$ The total no. of organisms of a particular species; $\mathrm{N}$ $=$ the total no. of organisms of all species]

Relative abundance $=\frac{\text { Number of the species }}{\text { Total number of the individuals }}$

\section{RESULTS AND DISCUSSION}

A total of 65 fish species were recorded from the Feni and Muhuri rivers in wet and dry seasons (Table 1, Fig. 2). From Feni river, 54 fish species (under 10 orders and 26 families) and from Muhuri river, 42 fish species (under 9 orders and 20 families) were recorded (Table 1, Fig. 2). Of these 65 fish species, a total of about 994 individuals were recorded from the selected rivers of which 566 individuals (299 in wet season and 267 in dry seasons) of the fish species (57\%) from Feni river and 428 individuals (280 in wet season and 148 in dry seasons) of fish species (43\%) from Muhuri river were recorded in both seasons during the study period (Fig. 3).

The Shannon-Wiener's and Simpson's diversity indices considered the richness and proportion of each species, while the evenness index represented the relative number of individuals in collected sample. The value of ShannonWeiner index was calculated as highest $\left(\mathrm{H}^{\prime}=1.286\right)$ in wet season from the Feni river and lowest $\left(\mathrm{H}^{\prime}=0.891\right)$ in dry season from the Muhuri river (Table 2). 


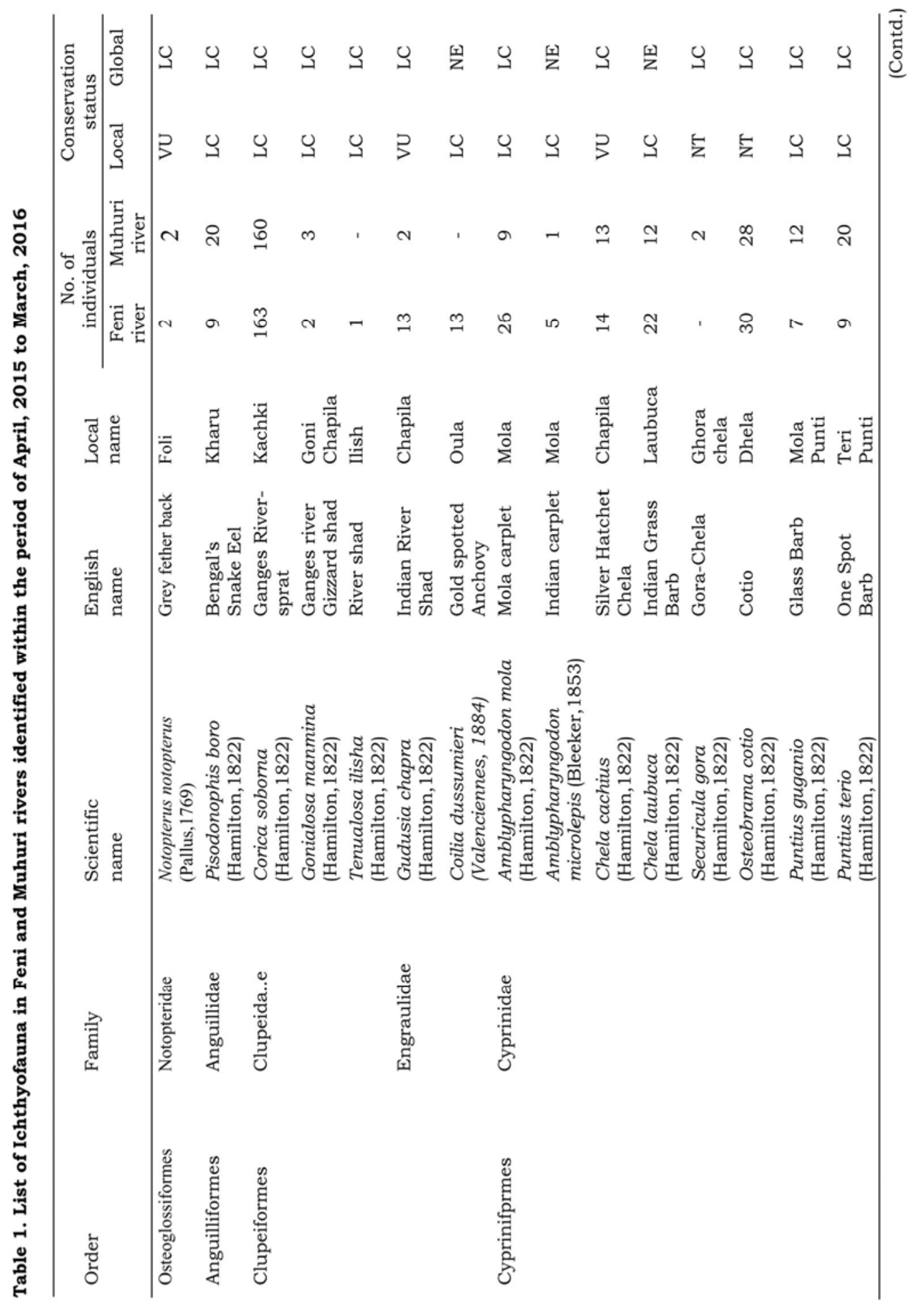




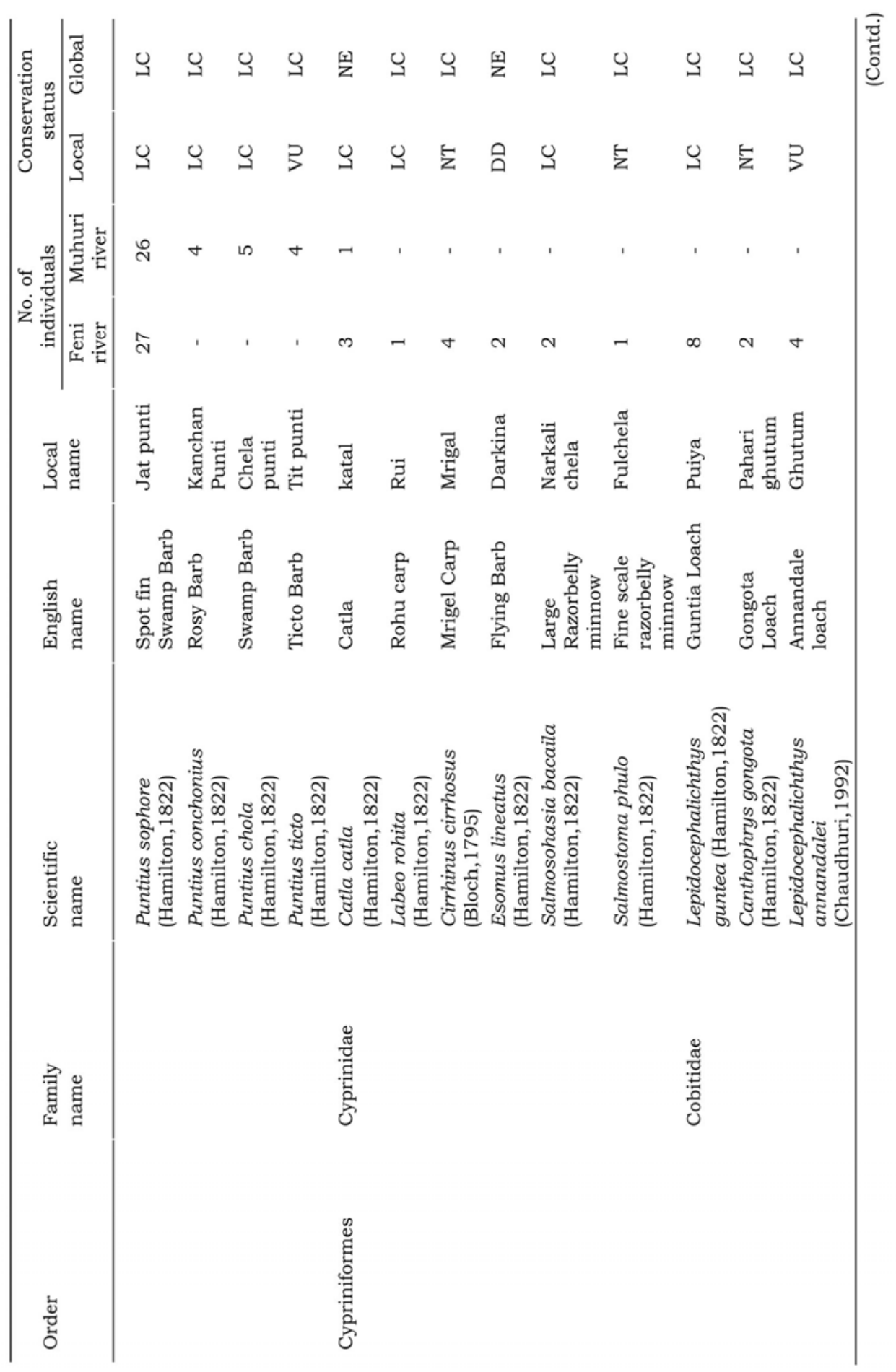




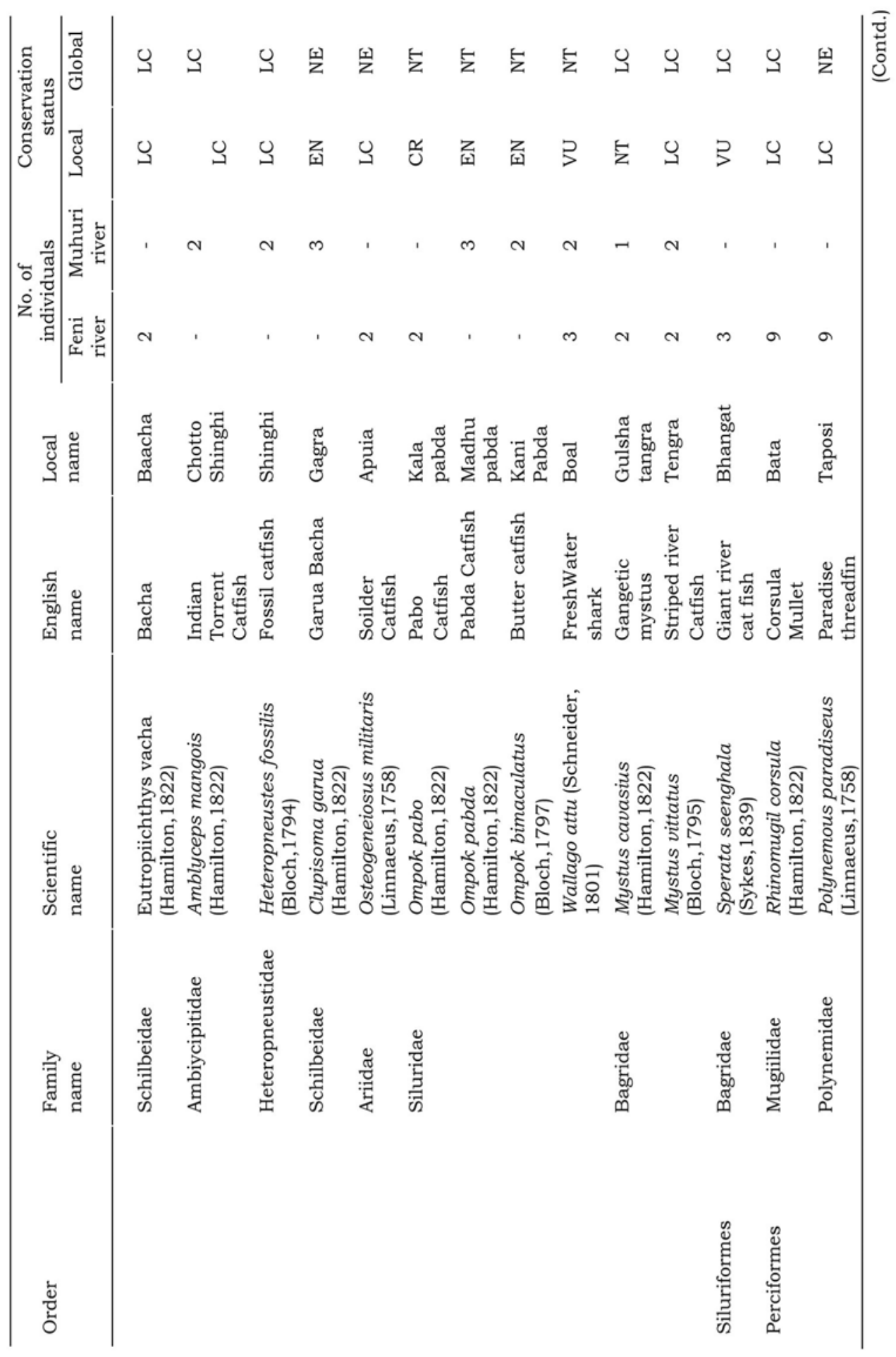




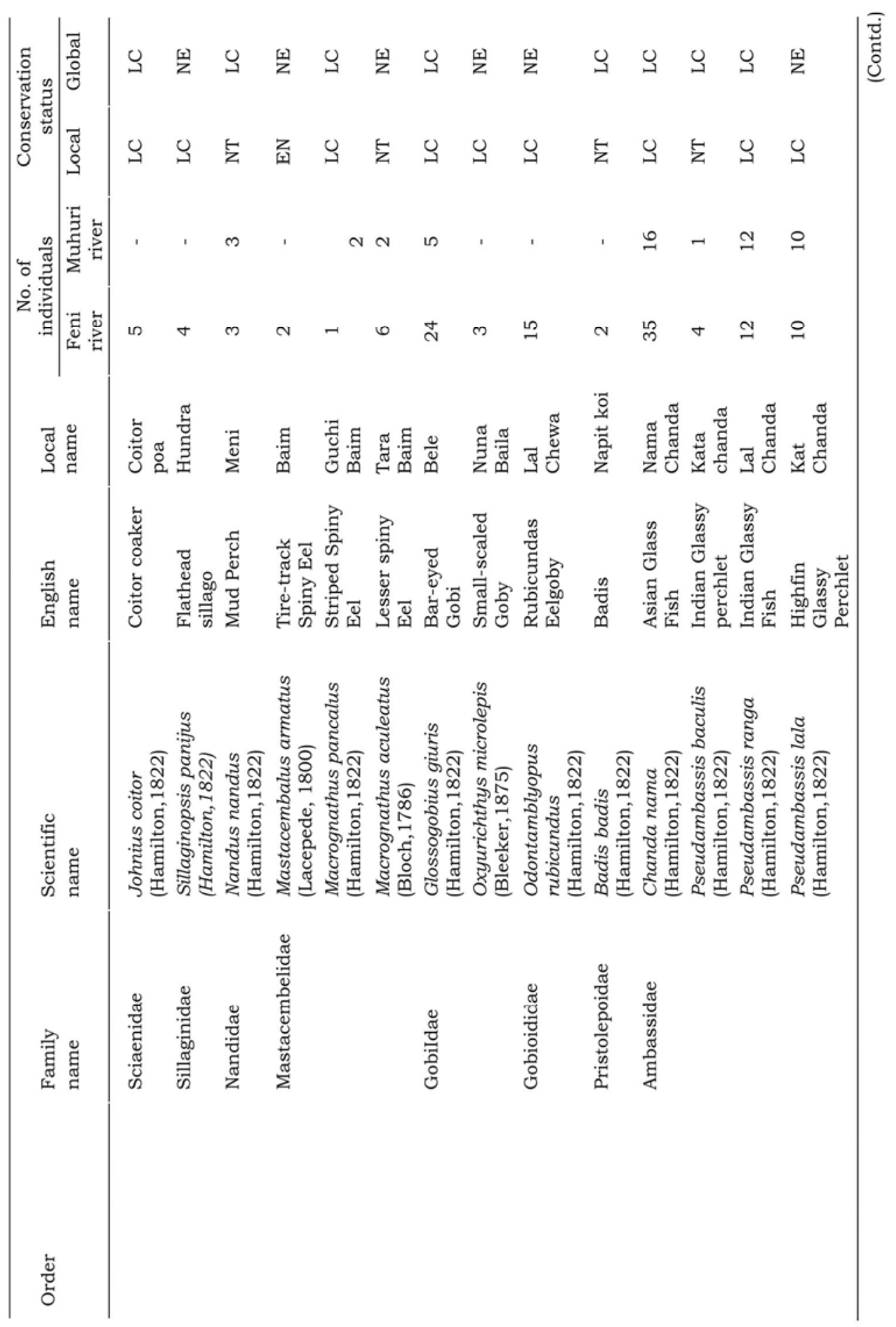




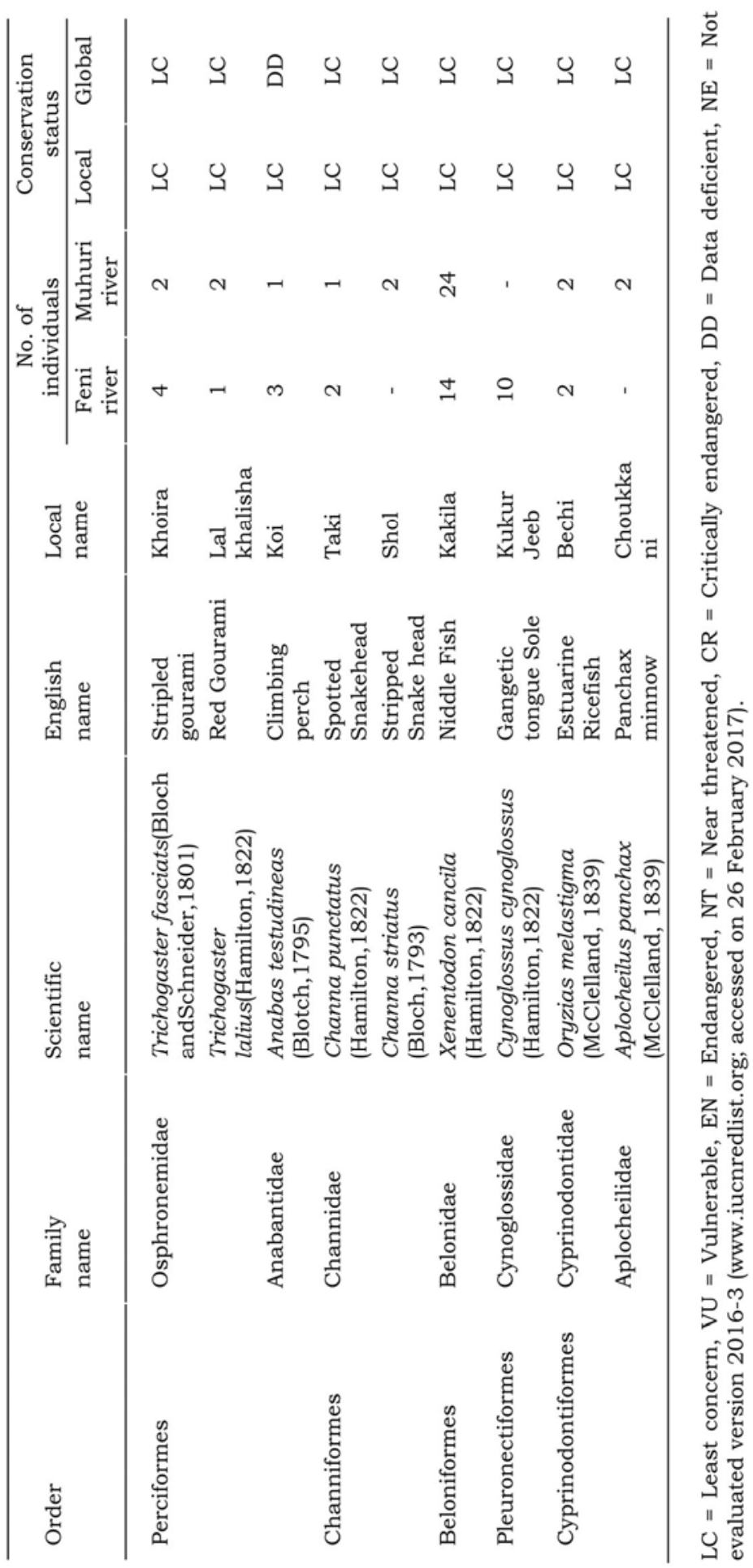


Similarly, value of Simpson's index of diversity was recorded as maximum ( $\mathrm{D}=$ 0.903 ) in wet season from the Feni river and as minimum $(D=0.740)$ in dry season from the Muhuri river (Table 2). These calculated values indicated that the species diversity was greater (Feni River $=40$ species and Muhuri river $=32$ species) in wet season in comparison to dry season (Feni river $=29$ species and Muhuri river $=20$ species) (Table 2). Most of the fish species recorded from the two rivers remain same but some exceptional fish species were recorded from the Feni river (Table 1) which also indicated that the ichthyodiversity of Feni River is higher than the Muhuri river (Table 2). Evenness value was highest (8.423) recorded from the Feni river in wet season whereas it was lowest (5.858) recorded from the Muhuri river in dry season (Table 2). High diversity in wet season also supported by Hossain et al. (2014).

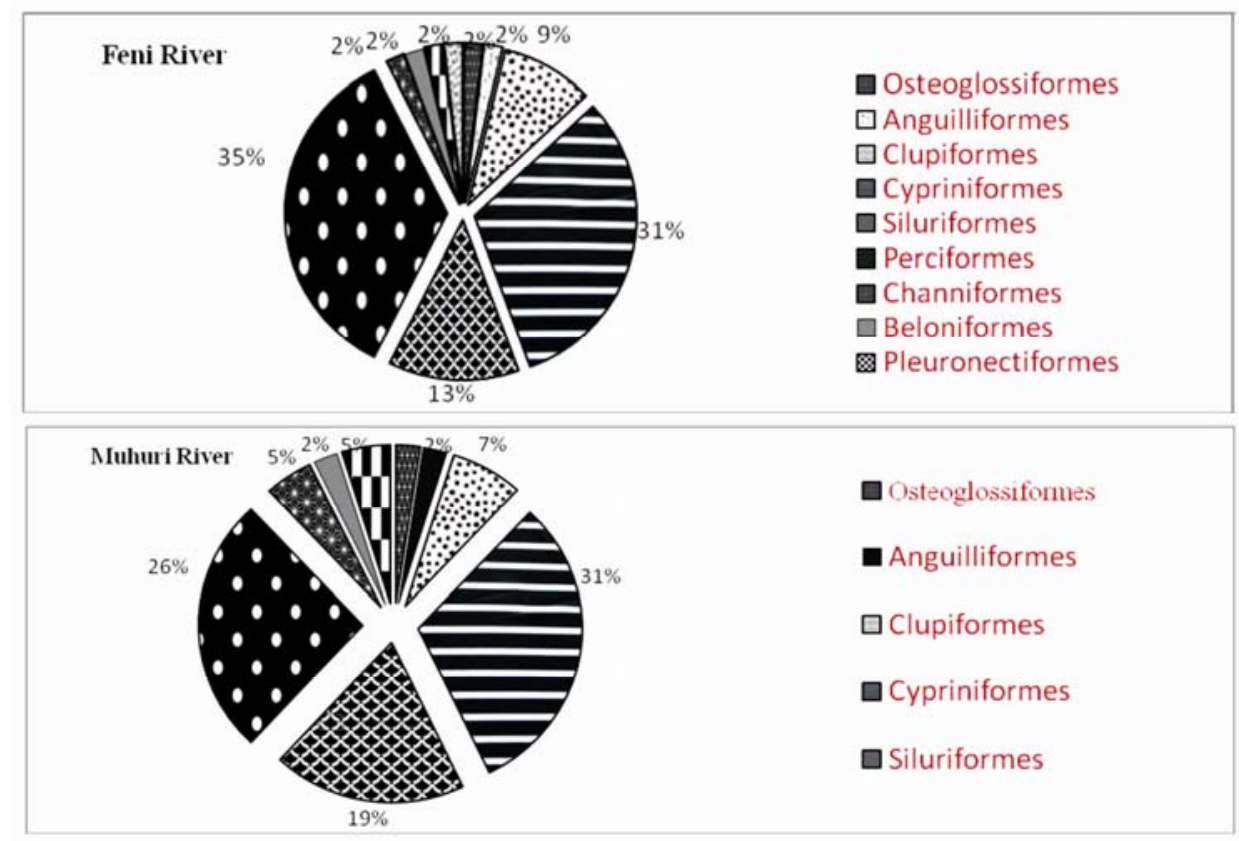

Fig. 2. Order-wise percentage composition of fish species recorded from the Feni and Muhuri rivers.

In 2015, IUCN Bangladesh reported 253 freshwaster fish species whereas, Siddiqui et al. (2007) reported 251 from all over Bangladesh (Table 3). Hossain et al. (2014) reported 128 fish species from the greater Noakhali (Table 3) that represents about $48 \%$ of the country's total fish species. Current study also highlighted that fish species recorded from the Feni and Muhuri rivers represented about $26 \%$ of country's total freshwater fish species. According to different researchers, species composition varies from place to place in different 
parts of Bangladesh due to different environmental conditions (Hossain et al 2014, Das and Sharma 2012).

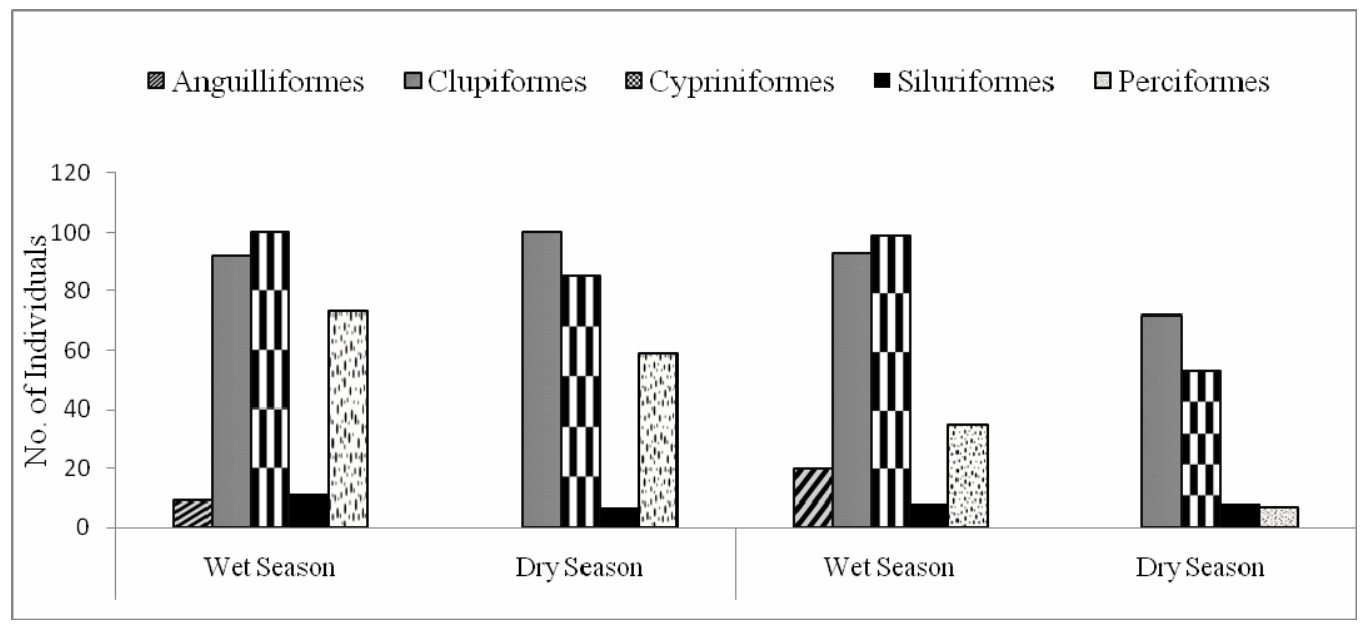

Fig. 3. Major orders of ichthyofauna observed in different seasons from two rivers.

Table 2. Various diversity indices used in this study to calculate fish species richness and evenness

\begin{tabular}{lcccc}
\hline \multirow{2}{*}{$\begin{array}{l}\text { Diversity } \\
\text { index }\end{array}$} & \multicolumn{2}{c}{ Feni river } & \multicolumn{2}{c}{ Muhuri river } \\
\cline { 2 - 5 } & Dry season & Wet season & Dry season & Wet season \\
\hline Shannon-Weiner Diversity index $\left(\mathrm{H}^{\prime}\right)$ & 1.188 & 1.286 & 0.891 & 1.172 \\
Simpson diversity index(D) & 0.874 & 0.903 & 0.740 & 0.872 \\
Pielou's evenness index(J') & 7.524 & 8.423 & 5.858 & 7.423 \\
Species observed & 29 & 40 & 20 & 32 \\
Individual observed & 267 & 299 & 148 & 280 \\
\hline
\end{tabular}

Due to the estuarine environment two migratory species Tenualosa ilisha and Cynoglossus cynoglossus were observed in Feni river which were not observed in Muhuri river. Hossain et al. (2014) also recorded Tenualosa ilisha from Feni river. There were some fish species diversity observed in both side of sluice gate of Feni river. In Feni River perciformes was the dominating group constitutes about $35 \%$ while the same order constitutes about $26 \%$ of fish fauna recorded from Muhuri river (Fig. 3). Whereas Cypriniformes constitutes about $31 \%$ of fish fauna from both Feni and Muhuri rivers. Cypriniformes was the most dominating group recorded from Muhuri river. The percentage of different fish orders recorded from the Feni and Muhuri rivers are given in Fig. 3. 
Corica soborna was the largest number found in both rivers. Order pleuronectiformes (e.g. Cynoglossus cynoglossus) is only found in the Feni river which is migratory in nature. Places with similar environmental characteristics might have influence to have similar specie compositions (Table 3). In addition, Feni river has an estuarine environment and constitutes both marine and freshwater fish species, while Muhuri river is the trans-boundary River between Bangladesh and India. That could be one of the reasons for the greatest icthyodiversity observed in the current study. In Feni river, Cypriniformes was the dominating group wet season and Clupiformes was dominating group in dry season. This condition is also same in Muhuri river. Anguiliformes was found in both rivers only in wet season. Fish species of Perciformes order found in large number Feni river more than Muhuri river. Siluriformes was the order of average number of individuals.

Table 3. Studies on freshwater fish species of Bangladesh in the past 50 years

\begin{tabular}{llll}
\hline Number of species & Number of family & Study areas & References \\
\hline 65 & 29 & Feni & Present study (2016) \\
253 & 45 & Bangladesh & IUCN Red List (2015) \\
128 & 34 & Noakhali & Hossain et al. (2014) \\
139 & 34 & Mymensingh & Chandra (2009) \\
251 & 62 & Bangladesh & Siddiqui et al. (2007) \\
165 & 55 & Bangladesh & Rahman (2005) \\
133 & 32 & Rajshahi & Bhuiyan et al. (1992) \\
106 & 34 & Mymensingh and Tangail & Doha (1973) \\
71 & 25 & Dhaka & Bhuiyan (1964) \\
\hline
\end{tabular}

IUCN (2015) Red list was consulted to assess the national and international conservation status of the recorded species (Table 1). Among the 54 fish species recorded from Feni river, 36 species rated as least concern (LC), 9 species rated as near threatened (NT), 6 species rated as vulnerable (VU), 1 rated as Endengered (EN), 1 rated as Critically endanger (CR) and 1 as data difficient (DD) (Table 1). Whereas, among the 42 species recorded from Muhuri river, 28 species rated as least concern (LC), 6 species rated as near threatened (NT), 5 species rated as vulnerable (VU) and 3 species rated as endengered (EN) (Table 1). Current study recorded about 17 threatened species (of different categories) from Feni river and 14 threatened species (of different categories) from Muhuri river. This study can be used as one of the base line data for further effective conservation management plan for threatened fish species of Bangladesh.

Current study observed that the Feni river estuary has high species diversity and it is higher in the estuarine mouth compared to that of upper stream 
direction which is also reported by Hossain et al. (2012). Species diversity observed in Feni and Muhuri rivers and geographical location was identified as the one of the reasons. Feni river is close to the estuarine mouth of the Bay of Bengal and Muhuri river comes from the upper stream of Belonia, India. Estuaries are the most productive ecosystem (Das and Sharma 2012, Hossain et al. 2014, Malmqvist and Rundle 2002). For that reason Feni River represented a great icthyodiversity. The number of order, families and species of fish recorded in this study represented that Feni and Muhuri rivers of Feni district, under the greater Noakhali can be considered as one of the rich and diverse resources. This finding supported the data recorded by Hossain et al. (2014). The ichthydiversity of these two rivers can be considered as one of the significant contributions to both the national economy and protein demand for Bangladesh.

\section{LITERATURE CITED}

AKONDA, A.W. 1989. Bangladesh. In: A Directory of Asian Wetlands. (ed. Scott, D.A.). IUCN, Switzerland. pp. 541-581.

ALLAN, J.D. and FLECKER, A.S. 1993. Biodiversity conservation in running waters. Identify the major factor that threatened destruction of riverine species and ecosystems. Bio. Science 43: 3243.

AMEEN, M. 1987. Fisheries Resources and Opportunities in Freshwater Fish Culture in Bangladesh. DANIDA Project Report, NRD-II Project, Noakhali. 1: 208-209.

BAILlIE, J.E.M., GRIFFITHS, J., TURVEY, S.T., LOH, J. and COLLEN, B. 2010. Evolution Lost: Status and Trends of the World's Vertebrates. Zoological Society of London, United Kingdom. pp. 1- 69.

BHUIYAN, A.L. 1964. Fishes of Dacca. Asiatic Society of Pakistan, Dacca. pp.148.

BHUIYAN, A.S., ISLAM, M.N. and HOSSAIN, M.T. 1992. A checklist of the fishes of Rajshahi. Rajshahi Univ. Studies, Part-B. 20: 287-306.

CHANDRA, K. J. 2009. Availability of fish fauna in some selected districts in Bangladesh. Bang. J. Anim. Sci. 38(1\&2): 151-163.

DAS, B. and SHARMA, S. 2012. Ichthyofaunal diversity of river Jamuna, Karbi Anglong, Assam. The Clarion. 1(1): 65-69.

DoF 2013. Matshya Saptaha Saranika. 2012. Department of Fisheries, Ministry of Fisheries and Livestock. The Government of the People's Republic of Bangladesh, Ramna, Dhaka. Bangladesh. pp. 144.

DOHA, S. 1973. Fishes of the districts of Mymensingh and Tangail. Bangladesh J. Zool. 1: 1-10.

DUdGEON, D., ARTHINGTON, A.H., GESSNER, M.O., KAWABATA, Z., KNOWLER, D., LEVEQUE, C., NAIMAN, R.J., PRIEUR-RICHARD, A.H., SOTO, D., STIASSNY, M.L.J. and SULLIVAN, C.A. 2006. Freshwater biodiversity: importance, status, and conservation challenges. Biological Reviews. 81: 163-182.

FRSS. 2015. Fisheries Statistical Report of Bangladesh.Fisheries Resource Survey System (FRSS), Department of Fisheries Bangladesh. 31: 57.

HAMILTON, F. 1822. An account of fishes found in the River Ganges and its branches Archibald Constable and Company, Edinburgh. pp. 405. 
HOSSAIN, M.A. 2012. Habitat and fish diversity: Bangladesh perspective. Wetlands 2: 2-03.

HOSSAIN, M.I., SIWAR, C., MOKHTAR, M.B., DEY, M.M. and JAAFAR, A.H., 2009. Socio-economic condition of fishermen in seasonal floodplain beels in Rajshahi District, Bangladesh. Research Journal of Social Sciences 4: 74-81.

ISLAM, S.N. and GNAUCK, A. 2008. Mangrove wetland ecosystems in Ganges Brahmaputra delta in Bangladesh. Int. J. Frontiers of Earth Science in China 2(4): 439-448.

IUCN Bangladesh. 2015. Red List of Bangladesh, Freshwater Fishes. IUCN, International Union for Conservation of Nature, Bangladesh Country Office, Dhaka, Bangladesh. 5: 3-359.

MALMQVIST, B. and RUNDLE, S.R. 2002. Threats to the running water ecosystem of the world. Environ. Conserv. 29: 134-153.

NISHAT, A., HUQ, S.M.I., BARUA, S.P., REZA, A.H.M.A. and KHAN, A.S.M. 2002. Bio-ecological Zones of Bangladesh. The World Conservation Union (IUCN), Bangladesh. pp.141.

RAHMAN, A.K.A. 2005. Freshwater Fishes of Bangladesh. 2nd ed. Zoological Society of Bangladesh, Dhaka. 394 pp.

RAHMAN, A.K.A., KABIR, S.M.H., AHMAD, M., AHMED A.T.A., AHMED, Z.U., BEGUM, Z.N.T., HASSAN, M.A. and KHONDKER, M. (eds.). 2009. Encyclopedia of Flora and Fauna of Bangladesh, vol.24. Marine Fishes. Asiatic Society of Bangladesh, Dhaka. 485 pp.

SIDDIQUI, K.U., ISLAM, M.A., KABIR, S.M.H., AHMAD, M., AHMED, A.T.A., RAHMAN, A.K.A., HAQUE, E.U., AHMED, Z.U., BEGUM, Z.N.T., HASSAN, M.A., KHONDKER,M. and RAHMAN, M.M. (eds.). 2007. Encyclopedia of Flora and Fauna of Bangladesh, vol.23. Fresherwater Fishes. Asiatic Society of Bangladesh, Dhaka. 300 pp. 